\title{
Research on the Exploitation of Sports Tourism Resources in National Nature Reserves
}

\author{
Jian Xiong ${ }^{1, a}$, Haizhou Xiong ${ }^{2}$ \\ ${ }^{1}$ Hainan Technology and Business College, Haikou, Hainan Province, China \\ ${ }^{2}$ School of Economics and Management, Hainan University, Haikou, Hainan Province, China \\ a419985168@qq.com
}

Keywords: nature reserve, sports tourism, resource exploitation.

\begin{abstract}
This study adopts the research methods of literature review and field research. By taking ten national nature reserves of Hainan Province as the research objects, this paper systematically analyzes the exploitation conditions and the present exploitation status of sports tourism resources in these nature reserves. It is found that these national nature reserves in Hainan have superior and extensive sports tourism resources. However, during the exploitation, some improvements remain to be done.
\end{abstract}

\section{Introduction}

Sports tourism refers to a kind of tourism activities with an intention of participating in sports or watching sports events, or a kind of tourism activities whose content is sports. It is based on sports resources and sports facilities, which attracts people to participate in sports activities and forms a new tourism of experiencing the nature. The tourists can enjoy the sports service during their tourism, such as, fitness, entertainment, leisure, communication and so on. These operating programs contribute to the harmony of people, the nature and our society. Sports tourism is an emerging sunrise industry original from tourism and sports industry. It is an important part of the sports industry and has prosperous future. According to the types of market, it is divided into leisure market, fitness market, match market, stimulation market, athletic market and other subdivided markets.

In this paper, we explore the sports tourism resources of ten national nature reserves in Hainan. While optimizing the ecological environment conditions, the integration of ecological resources and natural reserve sports tourism should be done, which would effectively contribute to the promotion of the sustainable regional economy development.

\section{Conditions of the Exploitation of Sports Tourism Resources in National Nature Reserve}

Significance of the exploitation of sports tourism resources and its economic foundation. Nature reserve is an important carrier of ecological civilization construction. Establishment of nature reserves is an effective approach to protect ecological environment and safeguard national ecological security. It can accelerate the transformation of economic development and realize the sustainable development. Developing sports tourism can improve the structure of tourism products, enrich the cultural system of tourism products and promote the development of tourism. In addition, it can stimulate the demand for sports and make sports industry a new economic growth point. Therefore, the combination of tourism and sports contributes to the win-win mode of tourism and sports industry and the promotion of national economic development.

There are more than 30 ethnic groups in Hainan Province. Some of them are native residents, such as, the residents of Li nationality, Miao nationality, Hui nationality and Han nationality. The culture of local folk sports there is abundant and the economy is rapidly developing. On January 4, 2010, The Central People's Government of the People's Republic of China stated Views on Promoting the Constriction of Hainan International Tourism Island, which proposed the general requirements of the development of Hainan international tourism island, to strength the construction of ecological civilization, to enhance the capacity for sustainable development and to build a world-class resort 
island of leisure and travelling until 2020. In 2012, the tourists both at home and abroad visiting to Hainan are 33,203,700 and the total tourism income is 37.9 billion yuan with an increase of $17 \%$. In recent years, while accelerating the development of international tourism island, the sports industry has also rapidly developed. The water sports are increasing, as well as the international competitions, which attracts a large number of tourists. They come to Hainan to watch sports events and travel. The international sports events contribute to the development of tourism industry in this international tourist island, the improvement of its transportation, communication, food service industry and an increase of its employment.

Analysis on sports tourism policies. On October 20, 2014, The Central People's Government of the People's Republic of China stated Views on Promoting the Development of Sports Industry and Accelerating the Sports Consumption. It proposed that it is necessary to accelerate the transformation of government functions and streamline administration and institute decentralization. All-in fitness should be a national strategy. The sports industry should be supported and be regarded as a green industry, as well as a sunrise industry. The trade barriers should be get rid of and the policy barriers should be cleared. In the report of 18th National Congress of the Communist Party of China, it was firstly proposed that we should promote green development, cycle development and low-carbon development and build a beautiful China. This provides a more scientific philosophy and methodology guidance to enhance China's capacity for sustainable development. While developing regional economy, the integration of tourism and sports industry contributes to the development of two industries, as well as the overall development of our country.

General introduction of sports tourism resources in nature reserve and analysis on its geographical environment. Hainan is located in China's southernmost. Its coastline is more than $1800 \mathrm{~km}$ and it is the second largest island following Taiwan. Hainan is located of the north of Vietnam and it is next to Southeast Asia. It is not far away from the most developed Pearl River Delta region in southern China. Although Hainan is located in the tropics, it still has tropical monsoon, sea and a large area of tropical rainforest. These help to form a pleasant climate with an average temperature between $22{ }^{\circ} \mathrm{C}$ and $25{ }^{\circ} \mathrm{C}$. Hainan has greatly abundant and tropical island tourist resources, such as, the sea, sunshine, beaches, forests, hot springs, tropical property and ethnic minorities and so on. In addition, its marine resources accounts for two-thirds of our country whole resources, which shows its potential development of marine tourism market.

The ten national nature reserves in Hainan Island are distributed in its eastern, southern, western, northern and central regions. The climate there is tropical rain forest climate and tropical monsoon climate. The hours of sunshine there is longer and the fresh air is humid, especially in winter. The warmer temperature there is suitable for outdoor sports and leisure activities.

Hainan Tonggu Mountain National Nature Reserve is located in Longlou Town, Wenchang City, which is in northeast of Hainan Island. It is in the border area of sea and land. And it is a comprehensive nature reserve which includes different ecosystems of maritime and terrestrial space. The protected objects include the evergreen tropical rain forest ecosystem and its wild animals, sea erosion, coral reefs and benthic organisms. The plant resources of Tonggu Mountain Nature Reserve include 984 species, belonging to 168 families and 629 genera. The animals there are 10 species of mammals, 20 species of birds and reptiles, amphibians and insects, etc. The landscapes in Tonggu Mountain are a 338-meter-high peak, Moon Bay with 25-km-long winding coastline, Da'ao Bay with over 1000-meter-long and “U” shaped white sand beach, Stone Park, Tonggu Mouth and Yunlong Bay. Tonggu Mountain has extensive evergreen tropical seasonal rain forest ecology. It is facing the sea and is suitable for hiking, climbing, swimming and diving.

Sanya Coral Reef is located in southern coastal areas of Sanya and its around islands. Coral reef area is a national marine nature reserve with large distribution area. The surrounding sea water is quite clear and is suitable for diving, which contributes to the visitors' understanding of the ocean, the observation and understanding of marine animals, as well as the features, living habits and environment adaptation of coastal animals.

Wuzhishan National Nature Reserve is located in central Hainan Province. This reserve is an area of mountains with the center of Wuzhishan, an 1868-meter-high peak. It has the tropical rainforest 
features of complex forest species composition, well developed community structure, abundant interlayer plants. Wuzhishan has a tropical rain forest climate with an average annual temperature of $20{ }^{\circ} \mathrm{C}$. It is neither cold in winter, nor hot in summer. Therefore, it is known as the "emerald city” , "natural air condition" and "natural oxygen bar" . The biodiversity of rainforest is suitable for leisure tourism and mountaineering. The whole length of Grand Canyon rafting in Wuzhishan is about 10km, dividing into two rafting stages, “Warrior Adventure" and “Happy Couple” .

The beautiful Dazhou Island is located in the vast sea of the southeast Hainan. It is facing Orchard Port of Wanning City across the sea. The stones in this island are unique and the sea is beautiful. We can enjoy the mountains and stones, the sea, sunrise and sunset. We can also dive to experience tropical sea sports events. The water around this island is quite clear. Generally, we can even clearly see the scene 5 to 10 meters under sea level. The colorful marine life is suitable for underwater fishing and photography. Therefore, swimming, diving and other sports would have a stronger advantage during the exploitation of Dazhou Island.

Table 1 The distribution of ten national nature reserves in Hainan Province

\begin{tabular}{|c|c|c|c|c|c|}
\hline Name & Location & Climate type & $\begin{array}{c}\text { Floor } \\
\text { surface } \\
\text { (hectare) }\end{array}$ & Protection objects & $\begin{array}{l}\text { Approved } \\
\text { time (year) }\end{array}$ \\
\hline $\begin{array}{l}\text { Tonggu } \\
\text { Mountain }\end{array}$ & $\begin{array}{l}\text { Longlou Town, } \\
\text { Wenchang City }\end{array}$ & $\begin{array}{c}\text { Tropical } \\
\text { rainforest }\end{array}$ & 4400 & $\begin{array}{c}\text { Tropical Evergreen } \\
\text { monsoon rains, dwarf forest } \\
\text { ecosystem }\end{array}$ & 2003 \\
\hline $\begin{array}{l}\text { Bawang } \\
\text { Mountain }\end{array}$ & $\begin{array}{l}\text { Sourtheastern } \\
\text { area of } \\
\text { Changjiang } \\
\text { County } \\
\end{array}$ & $\begin{array}{l}\text { Tropical } \\
\text { monsoon }\end{array}$ & 29980 & $\begin{array}{l}\text { Black gibbon and their } \\
\text { habitat ecological } \\
\text { environment }\end{array}$ & 1988 \\
\hline Shanhujiao & $\begin{array}{l}\text { Southern area } \\
\text { of Sanya City }\end{array}$ & $\begin{array}{l}\text { Tropical } \\
\text { monsoon }\end{array}$ & 8500 & $\begin{array}{c}\text { Synthetic coral, ahermatypic } \\
\text { coral, coral reef, ecosystem } \\
\text { and its biodiversity }\end{array}$ & 1990 \\
\hline Wuzhishan & $\begin{array}{c}\text { Central area of } \\
\text { Hainan }\end{array}$ & $\begin{array}{c}\text { Tropical } \\
\text { rainforest }\end{array}$ & 8012 & Rainforest biodiversity & 2003 \\
\hline $\begin{array}{l}\text { Jianfeng } \\
\text { Mountain }\end{array}$ & $\begin{array}{l}\text { Southwestern } \\
\text { area of Hainan }\end{array}$ & $\begin{array}{l}\text { Tropical } \\
\text { rainforest }\end{array}$ & 20170 & $\begin{array}{l}\text { Tropical virgin forest } \\
\text { ecosystems }\end{array}$ & 2002 \\
\hline Dongzhaigang & $\begin{array}{l}\text { Northeastern } \\
\text { area of Hainan }\end{array}$ & $\begin{array}{l}\text { Tropical } \\
\text { monsoon }\end{array}$ & 2500 & $\begin{array}{l}\text { Mangrove Wetland } \\
\text { Ecosystem }\end{array}$ & 1986 \\
\hline Dazhou Island & $\begin{array}{l}\text { Eastern coast } \\
\text { of Hainan }\end{array}$ & $\begin{array}{l}\text { Tropical } \\
\text { monsoon }\end{array}$ & 7000 & $\begin{array}{l}\text { esculent swift, coral reef, } \\
\text { island ecosystem and marine } \\
\text { ecosystem }\end{array}$ & 1990 \\
\hline Datian & $\begin{array}{l}\text { Western area } \\
\text { of Hainan }\end{array}$ & $\begin{array}{l}\text { Tropical } \\
\text { monsoon }\end{array}$ & 1314 & Vegetation and Cervus eldi & 1986 \\
\hline $\begin{array}{l}\text { Diaoluo } \\
\text { Mountain }\end{array}$ & $\begin{array}{l}\text { Southeastern } \\
\text { area of Hainan }\end{array}$ & $\begin{array}{l}\text { Tropical } \\
\text { monsoon }\end{array}$ & 38000 & $\begin{array}{c}\text { Cephalotaxus mannii, } \\
\text { Mudhuca hainanensis, } \\
\text { hopea, Hainan, pangolins, } \\
\text { peacock pheasants }\end{array}$ & 2008 \\
\hline $\begin{array}{l}\text { Yingge } \\
\text { Mountain }\end{array}$ & $\begin{array}{l}\text { South central } \\
\text { area of Hainan }\end{array}$ & $\begin{array}{l}\text { Tropical } \\
\text { rainforest }\end{array}$ & 50464 & $\begin{array}{l}\text { Biological species and } \\
\text { ecosystems }\end{array}$ & 2014 \\
\hline
\end{tabular}

\section{Current Status of the Exploitation of Sports Tourism Resources in National Nature Reserve}

Small-sized exploitation and imperfect system of sports tourism resources. According to the survey, the sports events in nature reserves are less than expected and most of them are small-sized. The accommodation, catering and transport facilities there are not quite convenient. The professional management organization and sports facilities are also lacking. Although the project of Grand Canyon Rafting in Wuzhishan is developed earlier, the transportation is poor and the surrounding 
accommodation and catering is not perfect. After drifting, the leisure facilities for the tourists are lacking. The long length of returning may be also taken into consideration by some tourists. Moreover, the water level of drifting upstream is also not enough, as well as reserve measures of water resource. In some seasons, even the amount of reserve measures is not enough. These make drifting non-regular. The security facilities and professional workers of drifting are not sufficient.

The nature reserve with rich marine resources always has less diving facilities and professional divers. The diving consumer prices are not uniform and the difference is quite large, which causes less participation. In addition, the nature reserve has not tried new products while present single sports tourism products cannot meet the tourists' needs and restrict the depth of sports tourism development.

Single structure of sports tourism population. The strongest feature of domestic sports tourism is the self-selection of activity subjects, and the diversity of activities and the comprehensiveness of activities utility. The population of demographic market of sports tourism is closely related to gender, ethnicity, age, education, occupation, family type and income. The number of the people participating in sports tourism at their own expense is rising. And watching various sports fitness competitions and performances during tourism and participating in sports activities become the main content. The main influence of residents' participation in sports tourism is our weak economy and the tourists' insufficient leisure time. Thus, the overall level of sports tourism consumption is still lower. Most tourists think that the accommodation in natural reserve surrounding is not quite convenient and its catering price is higher than expected. Moreover, the sports events are not enough. These factors all lead to a single structure of sports tourism population. The young prefer diving and swimming. Few of the old and the children participate in these activities due to the security and sports interest. Those special sports events with cultural connotation and regional folk culture and customs sports have not been developed according to regional climate, season, different environments, which would improve tourists' interests and increase their participation.

Lacking the co-ordination of sports tourism resources. The exploitation projects of sports tourism resources lack unified management. The investment is dispersed. The investment of companies and individuals is high. Although the sport tourism has a prosperous future, due to the sports facilities and transportation, catering, accommodation, security and other imperfect facilities in the nature reserves, there are only a small number of tourists participating in sports. And the sport cost is relatively higher. Sports tourism projects lack scientific development with unified planning in different stages. Its economic benefit is also lower. It does not take full advantage of culture, nor preserve the intrinsic value of culture, which would promote the organic integration of national traditional culture and modern culture and enrich sports tourism resources. The simple duplication and resources wasting would result in the destruction of national sports culture.

\section{Conclusions and Suggestions}

Conclusions: Hainan National Nature Reserves all have rich flora and fauna resources, superior climate and natural environment. Its potential development of sports tourism is huge. Currently, the exploitation of sports tourism in nature reserves is unitary. The phenomenon of duplication is obvious. The auxiliary facilities are inadequate, lacking public sports facilities and special sports events. The sports tourism structure needs to be further optimized.

Suggestions: Our government should play a leading role in co-ordination. And we need to improve laws and regulations, to strengthen the cooperation and exchanges of sports and tourism, to create sports tourism brands with features of current times and to cultivate world-class talents for sports tourism. During the exploitation of sports tourism, we should make an objective evaluation and rational planning, maintain ecological balance, establish outlooks of industry and benefits, integrate regional sports tourism resources and service, so that we could achieve the sharing of human resources, avoid duplicated construction, build sports tourism circle with excellent facilities, beautiful environment and first-class service, establish a sports tourism industry base of leisure and fitness and build a tourism industry chain. In addition, we could enhance the competitive advantages of overall resources and optimize the industrial structure of sports tourism. In the nature reserves with 
abundant flora and fauna resources, we could develop other sports, such as, mountain climbing, rock climbing, rafting, marathon, mountain biking and other wilderness survival sports. In the nature reserves with rich marine resources, we could develop some sports events, for instance, marine exploration, fishing, diving, swimming, surfing, island survival training and so on. These help visitors experience the feeling of returning to the nature and show their skills. While combining local folk sports and integrating travelling and sports tourism, we can satisfy the tourists' demands of sports and fitness. Meanwhile, we can increase local employment opportunities and enhance the economic efficiency, which contributes to the exploitation of relevant industries and the promotion of regional economic development.

\section{Acknowledgement}

Fund project: Achievements of General Projects supported by Foundation for Philosophy and Social Sciences of Hainan Province and Hainan Federation of Social Science Circles (Project No.: HNSK (YB) 15-114).

\section{References}

[1] The Central People's Government of the People's Republic of China. Views on Promoting the Development of Sports Industry and Accelerating the Sports Consumption [EB/OL].

http://www.gov.cn/zhengce/content/2014-10/20/content_9152.htm 2014.10.20

[2] The Central People's Government of the People's Republic of China. Reviews on Promoting the Constriction of Hainan International Tourism Island [EB/OL].

http://www.gov.cn/zwgk/2010-01/04/content_1502531.htm 2010.01.04

[3] ZHANG Qiang \& LIU Boli. Status of Sports Tour Market in Home and Abroad [J]. SICHUAN SPORTS SCIENCE, 2003 (2): 1-2.

[4] MIN Jian. Sports tourism and its definition [J]. JOURNAL OF WUHAN INSTITUTE OF PHYSICAL EDUCATION, 2002 (6): 4-6.

[5] WANG Guizhong. Discussion on Classification and Renewal of Sports Tourism Resource [J]. SPORT SCIENCE, 2003, 23 (4): 12-15.

[6] YANG Qiang. 20 Years of Research on Chinese Sports Tourism: Review and Prospect [J]. China Sport Science and Technology, 2011, 47 (5): 90-100.

[7] TANG Xiaoying. Current Research Situation and Analysis of Sport Tourism Abroad [J]. JOURNAL OF XI'AN INSTITUTE OF PHYSICAL EDUCATION, 2005, 22 (1): 36-38.

[8] HAN Zhongpei. A Research of Marketing Development of Sports-tour And Chinese Sports-tour Resources [J]. SPORTS \& SCIENCE, 2005, 26 (3): 39-41. 